\title{
O Haiti é aqui: primeiros apontamentos sobre os imigrantes haitianos em Balneário Camboriú - Santa Catarina - Brasil
}

\begin{abstract}
Resumo
O capitalismo global desenvolve-se com o desenvolvimento desigual de suas partes constituintes. Sua expansão pela América Latina engendrou, a partir da colocação na divisão internacional do trabalho pelas mãos do colonialismo, o fenômeno do capitalismo dependente, que vincula o desenvolvimento econômico e social de um país periférico às exigências e necessidades dos países centrais. Este processo histórico cria riquezas na periferia do sistema capitalista, as quais são apropriadas pelas empresas dos países centrais: é um desenvolvimento do subdesenvolvimento, fórmula central para se entender como o Haiti passou de colônia mais próspera do mundo no século XVIII a país mais pobre da América atualmente. Suas precárias condições de vida condicionam, historicamente, a formação de fluxos migratórios de saída do país. Este artigo objetiva analisar, à luz de um enfoque histórico sobre o país, as razões de estes fluxos estarem, atualmente, se direcionando para o Brasil. A hipótese é que a migração haitiana no Brasil tenha origens na própria presença, subimperialista, do Brasil no Haiti. A metodologia contempla uma abordagem teórica e qualitativa sobre a formação histórica dos fatores de expulsão do país e uma abordagem qualitativa sobre as principais características deste fluxo na cidade de Balneário Camboriú - SC, através de entrevistas e questionários semiestruturados com um grupo de 18 imigrantes haitianos residentes na cidade.
\end{abstract}

Palavras-chave: Haiti; Migração Internacional; Balneário Camboriú Santa Catarina.

\section{Para citar este artigo:}

MAGALHÃES, Luís Felipe Aires. O Haiti é aqui: primeiros apontamentos sobre os imigrantes haitianos em Balneário Camboriú - SC. Revista PerCursos. Florianópolis, v. 15, n.28, p. 223 256. jan./jun. 2014.

DOI: $10.5965 / 1984724215282014223$

http://dx.doi.org/10.5965/1984724215282014223
Luís Felipe Aires Magalhães

Doutorando em Demografia pela Universidade Estadual de

Campinas - Brasil. lufeaires@gmail.com 


\title{
Haiti is here: first notes about Haitians immigrants in Balneário Camboriú - Santa Catarina - Brazil
}

\begin{abstract}
The global capitalism develops with, not despite, the uneven development of its constituent parts. Its expansion in Latin America spawned from the placement in the international division of labor at the hands of colonialism, the phenomenon of dependent capitalism, which connects the economic and social development of a peripheral country to the demands and needs of the core countries. This historical process creates wealth in the periphery of the capitalist system, however these riches are appropriate for companies of central countries is a development of underdevelopment, central formula to understand how Haiti became the most prosperous colony in the world in the eighteenth century into the poorest country America today. The precarious condition of life in the country, historically, the formation of migratory outflows from the country. This article aims to analyze, in the light of a historical focus on the country, the reasons for these flows are currently moving into Brazil. The hypothesis is that the Haitian presence in Brazil has origins in the presence itself, under imperialist, Brazil in Haiti. The methodology comprises a theoretical and qualitative approach to the historical formation of deportation factors and a qualitative approach on the main characteristics of this flow in the town of Balneário Camboriú - SC, through interviews and semi -structured questionnaires with a group of 18 Haitian migrants residents in the city .
\end{abstract}

Keywords: Haiti; International migration; Balneário Camboriú - Santa Catarina. 
Neste artigo, abordaremos de forma preliminar algumas das principais características do fluxo, ainda recente, de haitianos rumo à cidade de Balneário Camboriú, no estado de Santa Catarina. Serão analisados, com base no resultado de entrevistas e aplicações de questionários semiestruturados, aspectos como trajeto da viagem, estadia na fronteira entre Brasil e Peru, clandestinidade predominante no fluxo, inserção no mercado de trabalho da cidade, remessas destes migrantes a seus familiares no país de origem, entre outros temas. Entendendo que estas questões são explicadas pela natureza histórica dos fluxos migratórios e pela produção da subalternidade étnica de que os haitianos são objeto, daremos especial ênfase ao estudo da história do Haiti, desde sua colocação no mercado mundial como a colônia mais próspera do mundo no século XVIII, até os recentes acontecimentos no país, como o terremoto de janeiro de 2010. Ademais, apresentaremos para análise e crítica uma interpretação do fato de este fluxo migratório desviar sua tendência histórica de rumar aos Estados Unidos, Canadá e França, e passar a dirigir-se ao Brasil. Esta interpretação é baseada na centralidade do fenômeno do subimperialismo brasileiro no Haiti, e na criação, a partir dele, de laços objetivos e subjetivos entre os dois países. Laços estes que condicionariam a formação do referido fluxo.

\section{Migrações internacionais no capitalismo contemporâneo: A produção da subalternidade e a acumulação de capital.}

A mobilidade internacional da força de trabalho é um fenômeno social (SINGER, 1995; MARTES, 2000) inscrito no marco da reprodução do capitalismo em escala global (GAUDEMAR, 1977; BRITO, 1995). A migração, enquanto veículo do povoamento da Terra, precede, no entanto, o desenvolvimento do Modo de Produção Capitalista. Este sistema específico de produção e distribuição da riqueza apropria-se da mobilidade da força de trabalho de forma também específica (GAUDEMAR, 1977). Entender como o sistema capitalista se apropria da mobilidade da força de trabalho exige uma prévia análise da importância dos Estados Nacionais e das fronteiras nacionais para i) a criação de um território consagrado às relações capitalistas de produção e ii) a criação de um conjunto de subalternidades, de classe, de cor, de crença e de origem, que cinde o gênero humano 
e o submete aos interesses do capital. Submete a estes interesses, inclusive, a própria mobilidade humana. A presença haitiana em Balneário Camboriú/SC guarda relação com estes dois processos.

Embora a natureza do capital seja universalizante (MARX e ENGELS, 1948/2009), no sentido de desconhecer fronteiras nacionais, é precisamente dentro destas que o capital desenvolve suas relações de produção, no trato direto com a força de trabalho e a institucionalidade que ele requer, sobretudo na garantia jurídica e no resguardo militar da propriedade privada.

A burguesia mercantil, que nascia da resistência e limites impostos à acumulação privada para o beneficiamento da Igreja católica e do jugo da nobreza, esta aristocrática, ocupada em manter o sistema de produção assentado na suserania e vassalagem, desde cedo aprendera a aliar-se com os vassalos, origem da classe trabalhadora e força principal de qualquer revolução, para a transformação da realidade. Foi assim que ela dobrou para si a resistência da Igreja católica, que, pelos escritos escolásticos de direito natural e pelas bulas papais passavam, gradativamente, a "permitir" o lucro comercial, a usura e a propriedade privada (SCHUMPETER, 1964). Foi assim que ela eliminou o domínio feudal, em sangrentas e estruturais modificações do status quo. Desta primeira revolução nascem as cidades, o sentimento nacional, o Estado Nacional e a própria Era Moderna. $O$ mundo fora refeito segundo a imagem e semelhança do capital, e as estruturas sociais, políticas e econômicas do mesmo modo. Este processo guarda, inicialmente, relação com um conjunto muito pequeno de países, situados à margem do Mediterrâneo, mantenedores de laços comerciais com alguns pontos isolados do oriente da Ásia mais próxima, e dos extremos do norte e nordeste da África (WILLIAMS, 1975; BAGÚ, 1977). Mas a revolução das formas de produção que o capitalismo inaugurava não podia ocuparse somente do mercado interno nestes Estados Nacionais (MARX e ENGELS, 1848/2009). Tão logo o lucro passa a operar todo o sistema de produção e isto a regular a vida social, o capital sai à procura de novos espaços de acumulação. E havia um vasto mundo a ser "recriado". 


\title{
Haiti: de colônia mais próspera do mundo a país mais pobre da América
}

A era das grandes navegações acelerou o processo de formação dos Estados Nacionais e das fronteiras nacionais. Foi esta era, justamente, o período de expansão global das relações capitalistas de produção e, por consequência, de formação das desigualdades nacionais.

\begin{abstract}
A descoberta da América e a circunavegação da África ofereceram à burguesia ascendente um novo terreno. $O$ mercado indiano e chinês, a colonização da América, o intercâmbio com as colônias e, em geral, a intensificação dos meios de troca e das mercadorias deram ao comércio, à navegação e à indústria um impulso até então desconhecido, favorecendo na sociedade feudal em desintegração a expansão rápida do elemento revolucionário (MARX e ENGELS, 1848/2009, p. 25).
\end{abstract}

Neste período, desenvolvem-se em escala global as relações capitalistas de produção (FRANK, 1973), tendo, conforme sugerido acima, inicialmente como motor as relações mercantis. Foi com a cruz do Catolicismo e com a bandeira de Portugal e Espanha (elementos que, na mente fértil de Darcy Ribeiro, o levaram a descrever estes impérios como Impérios Mercantis Salvacionistas) que o capitalismo mercantil aportou na América Latina, transformando as relações sociais e de produção aqui já existentes e orientando-as para a criação de excedentes comercializáveis e a extração de metais e outras matérias-primas (WILLIAMS, 1975; BAGÚ, 1977). As vicissitudes desta procura, a engenhosidade da máquina colonial exploradora de Portugal e Espanha, a resistência dos povos originários e a disputa com potências emergentes à época (Inglaterra, França e Holanda) foram os elementos centrais da formação, na América Latina, dos Estados Nacionais e da delimitação de suas fronteiras (CUEVA, 1990). O Haiti, pela magnitude que a exploração atingiu e a força da ruptura com o colonialismo que lhe seguiria, é um rico exemplo destas transformações.

Cristóvão Colombo pisou pela primeira vez em terras do Novo Mundo na ilha de São Salvador e, após louvar a Deus, saiu à procura de ouro. Os nativos, índios de pele vermelha, eram pacíficos e amistosos e indicaram- 
Ihe o Haiti, uma grande ilha (aproximadamente do tamanho da Irlanda), rica, diziam, do metal amarelo. Ele navegou para o Haiti. Quando um de seus navios naufragou, os índios dali ajudaram-no de tão boa vontade que muito pouco foi perdido e, dos artigos que levaram até a praia, nenhum foi roubado. Os espanhóis, o povo mais adiantado da Europa daqueles dias, anexaram a ilha, a qual chamaram de Hispaniola, e tomaram os seus primitivos habitantes sob a sua proteção. Introduziram o cristianismo, o trabalho forçado nas minas, o assassinato, o estupro, os cães de guarda, doenças desconhecidas e a fome forjada(pela desnutrição dos cultivos para matar os rebeldes de fome). Esses e outros atributos das civilizações desenvolvidas reduziram a população nativa de estimadamente meio milhão, ou talvez um milhão, para sessenta mil em quinze anos. Las Casas, um padre dominicano dotado de consciência, viajou para a Espanha para pleitear a abolição da escravatura de nativos. Mas, sem a coerção desses indígenas, como poderia a colônia existir? Tudo o que os nativos receberiam a título de salário seria o cristianismo e poderiam ser bons cidadãos sem trabalhar nas minas. O Governo espanhol concordou. Aboliu os repartimientos, ou trabalho forçado, por direito, enquanto os seus agentes na colônia os mantinham de fato. Las Casas, assombrado pela possibilidade de ver, diante de si, a total destruição da população no período de tempo de uma geração, recorreu ao expediente de importar os negros mais robustos da populosa África. Em 1517, Carlos V autorizou a exportação de quinze mil escravos para São Domingos. Assim, o padre e o Rei iniciaram, no mundo, o comércio americano de negros e a escravidão (JAMES, 2010, p. 19-20).

De tão rico em recursos naturais, o Haiti despertou, rapidamente, a cobiça de França, Holanda e Inglaterra, que tentaram por diversas vezes invadir a ilha. Em 1695 é assinado o Tratado de Ryswick, na Holanda, através do qual a Espanha concede à França o direito de propriedade sobre a parte ocidental de toda a ilha (JAMES, 2010). Desde este momento, os rumos do movimento de classes que dariam origem à Revolução Francesa e os rumos das revoltas coloniais dos negros escravizados no Haiti não se distanciaram mais (JAMES, 2010). Esta indissociabilidade é expressão do lugar central que o Haiti, colônia mais próspera de então, ocupava no desenvolvimento das relações capitalistas de produção:

O comércio de escravos e a escravidão estavam firmemente entrelaçados à economia do século XVIII. Três forças: os proprietários de São Domingos, a burguesia francesa e a burguesia inglesa prosperaram sobre a devastação de um continente e a brutal exploração de milhões de seus habitantes. Enquanto essas forças se mantivessem em equilíbrio, o tráfico demoníaco prosseguiria; e assim teria continuado até os dias de 
hoje. Mas nada, por mais lucrativo que seja, dura para sempre. Desde que o seu próprio desenvolvimento ganhou ímpeto, os fazendeiros das colônias e as burguesias francesa e britânica passaram a gerar pressões internas e a intensificar as rivalidades externas, dirigindo-se cegamente para conflitos e explosões que despedaçariam as bases do seu domínio e criariam a possibilidade da emancipação (JAMES, 2010, p. 39).

No cerne das contradições de uma expansão do exclusivismo comercial que, mais que enriquecer, encaminhava o Haiti a passos largos para a dependência estrutural, estavam as pressões do Império Britânico e de seu desenvolvimento industrial, que promoviam na Europa a ideologia do liberalismo em detrimento dos exclusivismos coloniais (JAMES, 2010). O Haiti estava no meio do fogo cruzado de um capitalismo em transformação, dentro do qual, todavia, nem o sistema colonial, tampouco o capitalismo industrial, Ihe poderiam oferecer saídas dignas de superação do subdesenvolvimento. Este futuro, que viria a ser o maior drama histórico do gênero humano no Novo Mundo, estava, nos idos do século XVIII e XIX, ocultado pela imagem de uma colônia que produzia riquezas inigualáveis - mas não para proveito próprio.

Prosperidade não é um problema moral e a razão de São Domingos era a sua prosperidade. O mundo ocidental, durante séculos, nunca conheceu tal progresso econômico. Por volta de 1754, dois anos antes do começo da guerra dos Sete Anos, havia na ilha 599 fazendas de açúcar e 3.379 de anil. Durante a guerra dos Sete Anos (1756-1763), a Marinha francesa, varrida dos mares pela Força Naval Britânica, não podia trazer os suprimentos dos quais a colônia dependia; o extenso contrabando de mercadorias não podia suprir a deficiência e milhares de escravos morriam de fome e o vertiginoso aumento de produção, embora contínuo, diminuiu. Mas após o Tratado de Paris de 1763 a colônia deu um grande passo à frente. Em 1767 exportou 35 mil toneladas de açúcar bruto e 25 mil toneladas de açúcar branco, quinhentas toneladas de anil e mil toneladas de algodão, uma certa quantidade de couro, de melado, de cacau e de rum. O contrabando, ao qual as autoridades faziam vista grossa, elevava os números oficiais em pelo menos vinte e cinco por cento. Não era apenas em quantidade que São Domingos se sobressaía, mas em qualidade (JAMES, 2010, p. 56).

Comércio de contrabando e tráfico de escravos, dois elementos fundantes da sociedade colonial haitiana, não foram entraves, mas sim motores do desenvolvimento 
do capitalismo, assim como o colonialismo não era um protocapitalismo ou précapitalismo, como apregoam determinadas teses do desenvolvimento social e econômico, mas sim a forma específica, sui generis, com que o capitalismo mundial se desenvolvia na América Latina (FRANK, 1973; MARINI, 2000). As duas mais fortes burguesias nacionais do século XVIII, a da França e a da Inglaterra, seja pelo comércio colonial, pelo tráfico negreiro ou pelo contrabando, eram financiadas pela extração das riquezas haitianas.

O comércio colonial era muito grande para a burguesia francesa, apesar de sua riqueza. A burguesia britânica, a mais bem-sucedida no comércio negreiro, vendia milhares de escravos contrabandeados todos os anos para os latifundiários franceses e particularmente para São Domingos. Mas, mesmo enquanto vendia os escravos para São Domingos, a burguesia britânica assistia ao progresso dessa colônia com preocupação e inveja. Depois da independência dos Estados Unidos em 1783, essa espetacular colônia francesa repentinamente deu um salto que quase duplicou a sua produção em 1783 e 1789 (JAMES, 2010, p. 60-61).

Mas o sistema capitalista mundial, que precisara do comércio colonial (e da escravidão) para a acumulação primitiva de recursos nos países de centro do capitalismo, não poderia continuar convivendo com ambos ao atingir a fase da Grande Indústria Moderna: os limites para a acumulação em escala global que a permanência dos exclusivismos (não britânicos) e a ausência de um mercado de consumo (de consumo das mercadorias industriais inglesas) que a sociedade escravista impunha, foram o centro do antagonismo, já histórico desde as guerras medievais, entre França e Inglaterra. Com a batalha industrial sendo ganha pela Inglaterra, a França viu-se às voltas não apenas com a falência dos negócios coloniais e negreiros com o Haiti, como também com a irrupção do mais original e fecundo processo revolucionário nacional e étnico no Novo Mundo: a Independência Haitiana (CASTOR, 2008; JAMES, 2010). Capítulo particular da história americana, a revolução nacional haitiana expôs ao mundo, na ferocidade em romper os grilhões da exploração colonial imposta pelos brancos, a força do revide de um sistema mundial que se ampara na hierarquização racial, que possui um conteúdo e um cometimento racial, além de nacional e de classe. 
Com a Revolução Francesa, os preceitos de liberdade individual não demoraram a encontrar os negros escravizados pelos franceses em território haitiano.

"Eles (os escravos) ouviam falar da Revolução (Francesa) e conceberamna à sua própria imagem: os escravos brancos da França se levantaram e mataram os seus senhores e, assim, passaram a gozar os frutos da terra. Isso era grosseiramente impreciso, de fato, mas eles haviam apanhado o espírito da coisa. Liberdade, Igualdade e Fraternidade" (JAMES, 2010, p. 87).

Liberdade, Igualdade e Fraternidade, além de todos os direitos humanos, individuais e coletivos, propagados desde a França, se somaram à libertação do domínio colonial sobre a nação haitiana para irromper um processo revolucionário sui generis, que evidenciou o que sabemos hoje: liberdade, igualdade e fraternidade apenas para alguns, não para todos. Como defendiam os governantes franceses da época, Napoleão Bonaparte à frente, "não trouxemos meio milhão de escravos das costas da África para torná-los cidadãos franceses" (JAMES, 2010, p. 123). Era o sucesso do empreendimento colonial francês o que estava em jogo, e a própria capacidade da burguesia (e nisto não apenas a francesa), de impor limites ao discurso e à prática revolucionários que a fizeram derrubar a aristocracia, para frear os ímpetos proletários - e anticoloniais. "A tomada da Bastilha no 14 de Julho fez mais do que intimidar o Rei e a Corte. Assustou a burguesia, que se apressou em formar a Guarda Nacional, excluindo dela estritamente os pobres" (JAMES, 2010, p. 75). Rapidamente, e motivado pelas pressões do capitalismo industrial britânico em expansão, surge na França um clamor pelo fim da escravidão, corporificado no grupo Amigos dos Negros. No imediato pós-revolução, o clamor era uma força real, sobretudo por que o movimento de insurreição dos escravos no Haiti já estava posto. Todavia, com o arrefecimento do caráter revolucionário da burguesia francesa e da república francesa em geral, a causa antiescravista perde força, e a burguesia colonial, instalada até a medula nos negócios com o Haiti e o tráfico de escravos, passa a defender renhidamente a sua posição de classe na estratificação social, eminentemente racial, da colônia, já com o apoio do novo governo francês. As disputas imperialistas entre França, Inglaterra e mesmo Espanha (a independência haitiana precedeu todas as libertações 
coloniais hispânicas na América Latina) levaram esta última a oferecer apoio militar aos escravos insurgentes, buscando, logicamente, recuperar o domínio da ilha, perdido desde o Tratado de Ryswick, em 1695:

\begin{abstract}
Naquele momento, os negros não sabiam onde estavam seus verdadeiros interesses. E se não sabiam não era por culpa deles, pois a Revolução Francesa, ainda nas mãos dos liberais e 'moderados', estava claramente inclinada a levar os escravos de volta à velha escravidão. Assim, quando os espanhóis em São Domingos ofereceram aliança aos negros contra o Governo francês, naturalmente aceitaram. Eis aqui homens brancos que lhes ofereciam armas, munições e suprimentos, reconhecendo-os como soldados, tratando-os como iguais e pedindoIhes que atirassem contra outros brancos (JAMES, 2010, p. 125).
\end{abstract}

Os escravos revolucionários, já organizados em tropas e buscando o controle sobre o território haitiano, não se alinharam de todo com a Espanha, por razões coloniais históricas e por não verem ali um aliado incondicional. Dado que o governo proveniente da Queda da Bastilha se fazia cada vez mais conservador, sucederam-se missões e mais missões militares francesas para exterminar os escravos revolucionários. Os líderes, figuras humanas tão grandiosas quanto ocultadas pela historiografia tradicional, foram mortos, ou em combate, no Haiti, como Jacques Dessalines, ou torturados sob fome e frio nos Alpes, como Toussaint L'Ouverture (JAMES, 2010):

Depois de uma luta tirânica contra 60 mil veteranos das conquistas napoleônicas, os ex-escravos sacodem a dominação colonial em 1804, no início do século 19, e proclamam a independência. A revolução se baseava em um consenso sobre a abolição da escravidão, a consolidação da independência e a construção de um novo país, no qual não se excluía de nenhuma maneira interesses múltiplos e contradições na nascente sociedade (CASTOR, p. 2008, p.12).

A independência formal fora obtida, mas o imperialismo tinha uma "lição" a dar aos escravos, pobres e negros do mundo: num misto de vingança e juízo final, por ordem de Napoleão, uma ofensiva francesa realizou um massacre gigantesco no Haiti, e ateou fogo e destruiu as fazendas e demais instalações e bases produtivas do país. Se não 
pertencesse o Haiti à França, que não pertencesse o Haiti a ninguém. E se não fosse um país capitalista governado por brancos, ainda que pobre como a grande maioria dos países no mundo, que também não pudesse florescer ali um povo livre. O resultado foi a esterilização completa do solo haitiano, e uma marginalização global que transformou a outrora colônia mais próspera do mundo a país mais miserável da América, sob olhos e mãos atentos do imperialismo.

O desenvolvimento do capitalismo no Haiti, especificamente dependente, é produto e produtor do comércio colonial, das revoltas escravas, da independência negra a $1^{\circ}$ de Janeiro de 1804 e da marginalização secular do país pelo imperialismo. Estes processos se inserem na criação e reprodução de subalternidades étnicas e de classe, elementos fundantes da apropriação pelo capital da mobilidade internacional da força de trabalho haitiana (COVARRUBIAS, 2010).

Analisando em perspectiva histórica, o Haiti reproduz sistematicamente fatores estruturais de expulsão de sua força de trabalho: não se trata de um país não capitalista, mas sim de um país capitalista dependente cujas relações de produção são incapazes de incorporar as próprias massas à produção, ao consumo e a formas dignas de existência.

A população do país, atualmente, é de 10.255.644 habitantes, dos quais 44,5\% em condição de subnutrição. Apenas $17 \%$ têm acesso à rede sanitária, razão pela qual a maior parte das causas de morte, as infecto-parasitárias, deriva de razões que poderiam ser facilmente evitadas. A cólera, por exemplo: piorada após o terremoto de janeiro de 2010, poderia ser superada com melhorias simples no sistema sanitário e no de tratamento de água. A despeito destes dramas nacionais, apenas 1,5\% do PIB é investido em saúde. Dentre os habitantes, $34,7 \%$ não são alfabetizados. Em média, consomem $2.080 \mathrm{kcal}$ ao dia, mesma quantidade de calorias que no lêmen e na Tanzânia. É tudo o que dá para consumir dentro deste contexto de crise alimentar permanente, dado que $61,7 \%$ vivem com menos de um dólar ao dia, patamar internacionalmente convencionado para definir a "linha da pobreza". Como apenas $26,1 \%$ dos partos são assistidos por profissional de saúde qualificado, em 350 de cada 100.000 nascidos vivos a mãe não sobrevive ao parto. Setenta em cada mil crianças morrem até os cinco anos de idade. Segundo dados do IBGE, cinquenta e três morrem antes de completar um ano de vida (IBGE, 2014). Por outro 
lado, 84\% dos egressos universitários haitianos passam a viver fora do país ao término de seus cursos superiores, o que revela o elitismo e distância do ensino superior em relação aos problemas nacionais mais dramáticos (World Bank, 2012).

\section{Imperialismo e migração: a rota Haiti - Estados Unidos}

As condições precárias de vida no Haiti engendram a atuação sistêmica de fatores de expulsão da população, a impelindo a emigrar (DURAND, 2013). Seja para quem obteve ensino superior, e que não encontrará aplicação financeiramente vantajosa aos seus ofícios no país, seja para os mais pobres, sem recursos e sem garantias de vida, cujo trabalho não Ihe permite uma vida digna, migrar para outros países, como os Estados Unidos, é uma possibilidade sempre presente. Atualmente, 1.134.000 haitianos residem fora do país, isto é, $11,05 \%$ da população, segundo dados do Migration International Institute (MPI, 2013) ${ }^{1}$. Historicamente, os Estados Unidos são o destino preferencial, pela proximidade, pela atuação das redes sociais, por sua economia e, principalmente, pela atuação do imperialismo norte-americano. São 664.000 os haitianos residentes neste país. A seguir, os destinos mais comuns são a França, com 77.000 emigrantes, o Canadá, com 70.000 emigrantes, e Bahamas, onde 40.000 atuam no sistema hoteleiro da região ou apenas usam as ilhas como etapa migratória para os Estados Unidos.

Como fluxo representativo, a presença haitiana nos Estados Unidos é registrada desde a primeira metade do século XX, embora haja relatos de emigração massiva durante a época sangrenta das lutas de independência (JAMES, 2010), na passagem do século XVIII ao XIX. De 1960 até 2010, o total de emigrantes passou de 5.000 para 606.000, chegando, atualmente, a representar 1,5\% de toda a população imigrante norteamericana (MPI, 2013). O gráfico I apresenta, para estas décadas, a evolução dessa emigração:

\footnotetext{
${ }^{1}$ Existem outras fontes de dados que apontam para um número maior de emigrantes haitianos. Optamos, todavia, pelas informações do MigrationPolicylnstitute em razão de se tratar de uma fonte regular, periódica e com acompanhamento sistemático da questão. Há, de fato, uma grande dificuldade na estimativa do volume migratório total, dificuldade esta aprofundada pelo caráter ilegal de grande parte destes emigrantes. A escolha pela referida fonte deu-se, então, por privilegiar a qualidade do dado.
} 


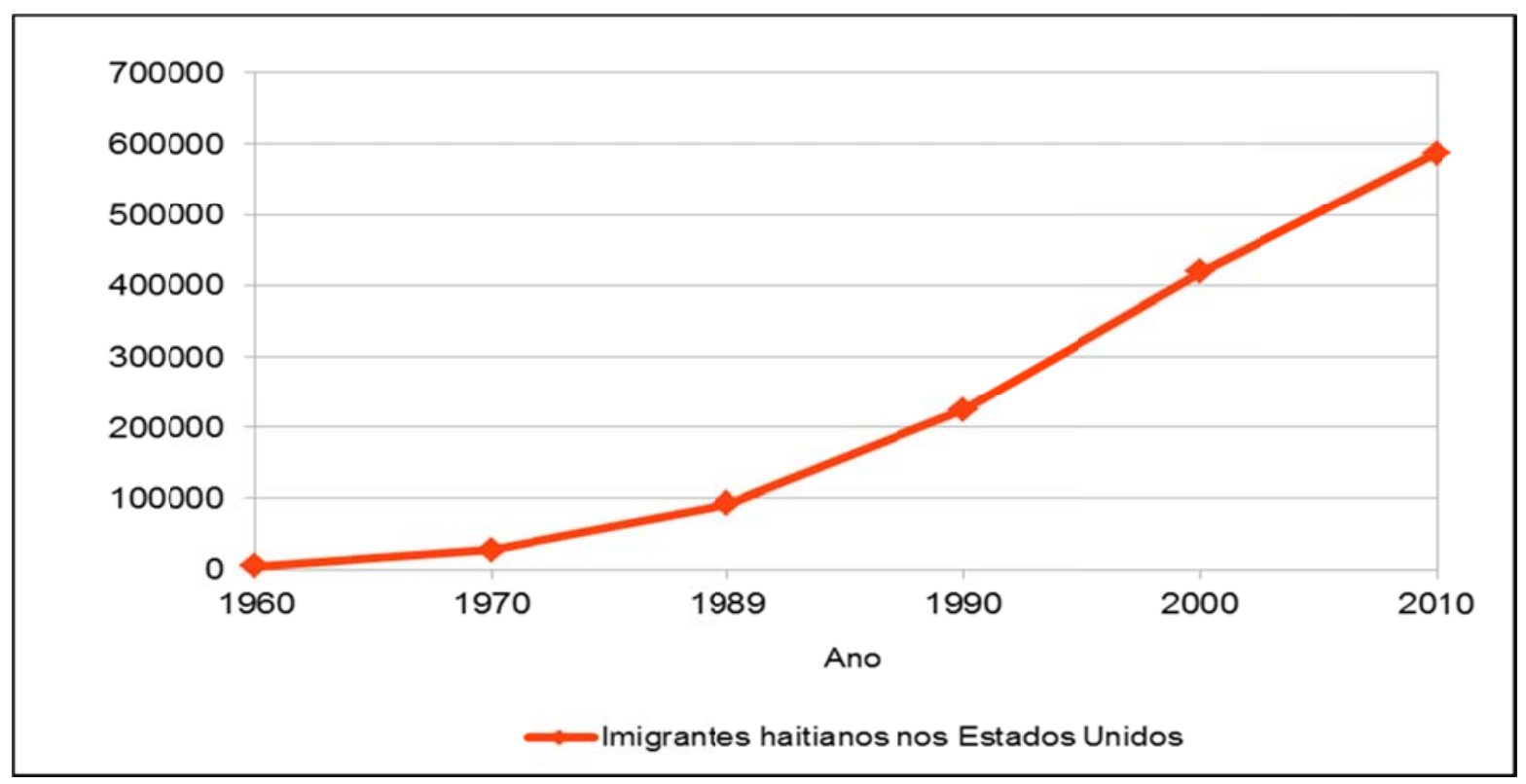

Fonte: MPI, 2013.

A Independência Negra do Haiti não representou, historicamente, a ruptura com o sistema capitalista, criador das subalternidades e promotor do desenvolvimento econômico e social dependente. Se foi verdade que o sistema colonial substituiu a Espanha pela França, também é verdade que o capitalismo industrial, ao atingir a etapa imperialista, substituiu a França pelos Estados Unidos (CASTOR, 2008; JAMES, 2010). A expansão norte-americana não poderia buscar o domínio das áreas mais distantes se não conquistasse, antes, o domínio sobre seus vizinhos. É o que ocorre no início do século XX:

o imperialismo nascente leva os Estados Unidos a considerarem toda a América Latina como sua zona de expansão natural e o Caribe como seu quintal. Assim, em 1915, o desembarque dos marines estadunidenses inicia a ocupação mais longa (1915 - 1934) na zona do Caribe e América Central. A crise de hegemonia se resolve de fato e a modernidade procurada se traduz na ordem estabelecida pelo ocupante a partir de uma reacomodação do poder político com o exército, recém-criado como coluna vertebral (CASTOR, 2008, p. 12).

Militar e economicamente, os Estados Unidos se tornam força fixa no Haiti no século XX, dominando diretamente suas escassas estruturas produtivas e influenciando, 
sob as mais variadas formas, a política nacional de acordo com o interesse das empresas norte-americanas. As últimas décadas do século XX, particularmente, aprimoraram esta dinâmica, intensificando a polarização de classe no país e agravando as condições sociais de tal modo que o consenso nacional se torna secundário frente à necessidade de uma solução armada dos conflitos sociais (CASTOR, 2008): sucessivos golpes e deposições se tornam a face mais visível de um país dramaticamente desigual. A presença militar externa requeria ser renovada, justificada, para a manutenção da estrutura social e econômica no país. Neste contexto, a ONU interveio, com o exército brasileiro à frente, através da Missão das Nações Unidas para a estabilização no Haiti (Minustah)².

Com o terremoto que atingiu o Haiti, em 12 de janeiro de 2010, e que causou a morte de mais de 200.000 pessoas, deixando mais de 1,5 milhão sem abrigo e inaugurando um novo ciclo trágico de contágio e morte por cólera, as condições de vida, que já eram precárias, se deterioraram ainda mais. Hospitais, escolas, prédios públicos e universidades foram destruídos, e isto se torna ainda mais trágico se pensarmos que tais estruturas já eram muito limitadas e incapazes de absorver os haitianos antes mesmo do abalo sísmico. A existência humana tornava-se cada vez mais difícil, de modo que se intensificaram os fatores de expulsão sobre a dinâmica migratória. Todavia, a conjuntura econômica internacional havia mudado desde os anos 1960: um conjunto de alterações, historicamente engendradas, colocou o Brasil na rota dos emigrantes haitianos. É preciso entendê-las para analisar com mais precisão as especificidades deste fluxo migratório.

\section{Subimperialismo e migração: a rota Haiti - Brasil}

Buscaremos a partir desta seção introduzir uma categoria analítica no estudo da migração haitiana no Brasil: a categoria do subimperialismo. Visamos, com isto, contribuir com o estudo deste fluxo e com a própria teoria migratória, estabelecendo um marco interpretativo sobre as migrações que contempla a análise dos conceitos de desenvolvimento, subdesenvolvimento e dependência. Da mesma forma que um

\footnotetext{
${ }^{2}$ Missão das Nações Unidas para a estabilização no Haiti ou MINUSTAH (sigla derivada do francês: MissiondesNationsUniespourlastabilisation em Haïti).
} 
conjunto de autores cunhou a expressão "migrantes coloniais" (BINFORD, 2007; COVARRUBIAS, 2010), para designar o fluxo migratório que parte de uma ex-colônia e se dirige a uma ex-metrópole (como os caribenhos nos Estados Unidos, os equatorianos e peruanos na Espanha, os africanos na França, Bélgica, Holanda e Portugal, por exemplo), vislumbramos aqui definir fluxos migratórios condicionados pela presença (econômica, política e militar) do Brasil no Haiti. O fenômeno do subimperialismo, neste sentido, é crucial.

Primeiramente, deve-se destacar que o Haiti é objeto, secular, da presença econômica e militar estrangeira (CASTOR, 2008), seja com o domínio colonial no século XVIII, com o controle político e militar dos Estados Unidos no século XX, e com a presença brasileira no início do século XXI. A presença estrangeira opera como uma instituição militar, econômica e política fundamental da sociedade nacional, dado que as "ajudas" internacionais representam em torno de $60 \%$ do orçamento do país, enquanto as remessas dos emigrantes algo em torno de $150 \%$ do valor total das exportações haitianas. Pela presença externa, calcula-se que vivam no Haiti 7.200 soldados, 1.500 policiais e incontáveis especialistas e trabalhadores civis (CASTOR, 2008). É neste contexto de primazia do externo e subordinação a este que se insere a Minustah:

A resolução 1.592 de fevereiro de 2004 adotada pelo Conselho de Segurança das Nações Unidas acordou, para estabilizar o Haiti, o desenvolvimento imediato de uma força rápida interina seguida de uma força multinacional para assegurar uma intervenção em longo prazo. Esta missão internacional de manutenção da paz, a Minustah, era a sexta implementada no país no lapso de um decênio (CASTOR, 2008, p. 18).

A relação metrópole e satélite, com a expansão do capitalismo industrial e a monopolização crescente do capital especialmente após a Segunda Guerra Mundial, complexificou-se. Ao esquema clássico de uma metrópole e colônias e satélites, foi adicionado um conjunto de países que ocupa posição intermediária na acumulação de capital em escala global. São países dependentes, pois inseridos na divisão internacional do trabalho de forma periférica, porém o desenvolvimento do capitalismo neles gerou 
uma expansão industrial cuja mais-valia criada seu mercado interno não tinha condições de absorver, pela restrição do consumo (LUCE, 2011; MARINI, 2012). Tendem, seja para realizar esta mais-valia, seja para buscar matérias-primas e fontes energéticas e naturais, a se expandir em países que ocupam posições ainda mais subalternas na divisão internacional do trabalho. Em outras palavras, a produção capitalista, mundializada, condicionou níveis intermediários de acumulação, de composição orgânica do capital. São os chamados países de semi periferia. Todavia, características específicas do capitalismo nos países semiperiféricos fazem com que alguns deles se tornem subimperialistas: a expansão industrial no exterior visando à realização da mais-valia criada internamente e o acesso a uma força de trabalho mais barata, à exportação de manufaturas e ao controle de recursos energéticos e naturais de outros países (LUCE, 2011; MARINI, 2012). Sobre o subimperialismo, Ruy Mauro Marini, afirma:

na prática, isso se traduz, em primeiro lugar, no impulso da economia brasileira em direção ao exterior, no afã de compensar sua incapacidade de ampliar o mercado interno através da conquista de mercados já formados, principalmente na América Latina. Esta forma de imperialismo conduz, no entanto, a um subimperialismo. Efetivamente, não é possível para a burguesia brasileira competir em mercados já repartidos pelos monopólios estadunidenses (...). Não lhe resta, portanto, outra alternativa a não ser oferecer a estes uma sociedade no próprio processo de produção no Brasil, usando como argumento as extraordinárias possibilidades de lucros que a contenção coercitiva do nível salarial da classe operária contribui para criar. O capitalismo brasileiro se orientou, assim, rumo a um desenvolvimento monstruoso, posto que chega à etapa imperialista antes de ter conquistado a transformação global da economia nacional e em uma situação de dependência crescente frente ao imperialismo internacional. A consequência mais importante desse fato é que, ao contrário do que ocorre com as economias capitalistas centrais, o subimperialismo brasileiro não pode converter a espoliação que pretende realizar no exterior em um fator de elevação do nível de vida interno, capaz de amortecer o ímpeto da luta de classes. Em vez disso, devido a sua necessidade de proporcionar um sobrelucro a seu sócio maior estadunidense, tem que agravar violentamente a exploração do trabalho nos marcos da economia nacional, no esforço para reduzir seus custos de produção (MARINI, 2012, p. 156-157). 
Sob o véu da liderança das forças de paz no Haiti (Minustah), a presença brasileira no país é condicionada pelos fatores acima descritos, o que explica a forte presença de empresas brasileiras no mercado local e a ação estratégica especialmente das empresas que se ocupam da reconstrução do país, como as empreiteiras e as grandes construtoras. O subimperialismo brasileiro, portanto, utiliza-se de uma aparência benévola, no sentido que lidera forças de estabilização e de paz no país, não obstante sua essência econômica, material, residir na busca por fontes energéticas e naturais e no lucro extraordinário oferecido pelo vantajoso negócio das (re)construções. Na correlação de forças do subimperialismo brasileiro, a presença no Haiti constitui uma especificidade, pois é o único país “ocupado" pelo Brasil em que a dimensão militar desta presença se sobrepõe à dimensão econômica, embora esta seja a determinante. O conceito de "cooperação antagônica" (LUCE, 2011; MARINI, 2012) é essencial para elucidar esta questão: embora a atuação brasileira no país se dê no sentido das forças de estabilização e contenção dos movimentos sociais e populares, no resguardo da estrutura de classes interna e na manutenção dos interesses capitalistas na região (cooperação com o capitalismo mundial, especialmente com o imperialismo norte-americano), existe um alto grau de especificidade dos próprios interesses nacionais brasileiros no país (antagonismo com outras forças imperialistas, como Estados Unidos e França).

O que interessa reter é que a presença brasileira, seja militar ou econômica, apresenta um "Brasil potência", sob a forma de uma baioneta de fuzil ou de máquinas de construção, a milhões de haitianos sem perspectivas de reprodução social de sua existência. Como indicado por Saskia Sassen (1988), esta presença estrangeira incide objetiva e subjetivamente na vida dos habitantes locais, inserindo em seu imaginário e em seu projeto migratório a possibilidade de se mudar para outro país. Historicamente, o sistema capitalista mundial cria e recria estes laços, levando muitos autores a conceituar estes migrantes de "migrantes coloniais" (BINFORD, 2007; COVARRUBIAS, 2010). O caso do Brasil e sua presença subimperialista no Haiti, no entanto, é um fenômeno diverso: o Haiti não é e nunca foi colônia brasileira. A própria presença brasileira no país é relativamente recente, como são recentes os fluxos de haitianos para o Brasil. Há uma relação íntima entre a presença do Brasil no país e a vinda dos primeiros haitianos ao 
Brasil. Esta relação nos leva a refletir, ainda que de forma breve e inicial, na capacidade de o subimperialismo condicionar a dinâmica migratória internacional, e criar e impulsionar um fluxo específico entre o país objeto da expansão subimperialista e o país que a promove efetivamente. Esta especificidade precisa ser investigada.

Teresa Sales (1996) embora não utilize o conceito de subimperialismo, não hesita em relacionar a migração de paraguaios ao Brasil com o fenômeno da expansão da propriedade das terras paraguaias por fazendeiros e empresas brasileiras. E vai inclusive além: insere esta presença brasileira no país vizinho no âmbito da dinâmica expansiva da agricultura brasileira, que se alastra pelos países do Cone Sul, mantendo o padrão agrário concentrador, latifundiário, e da oposição a este modelo, analisando concretamente as lutas travadas no campo e o surgimento do MST. Trata-se de uma pista importante de como o desenvolvimento do capitalismo dependente no Brasil, que engendra o fenômeno do subimperialismo, impulsiona o capitalismo brasileiro ao exterior e motiva a criação de fluxos migratórios particulares. Estes fluxos, como aponta o caso específico dos paraguaios, movem milhares de migrantes para as cidades brasileiras. Esta percepção é reforçada por Neide Patarra (2012). Ao referir-se à deterioração das condições econômicas e sociais no Haiti, Patarra (2012), afirma que

neste quadro, a presença do Brasil no Haiti, no comando da Missão das Nações Unidas para a Estabilização do Haiti - MINUSTAH, iniciada em 2004, foi fator de fundamental importância na inserção do país no quadro dos destinos procurados pelos haitianos que buscavam fugir da miséria e da desordem social (PATARRA, 2012, p. 13).

O Paraguai é um caso tão explicativo quanto o haitiano: os fazendeiros brasileiros controlam algo em torno de $13 \%$ da quantidade de terras no país, e $20 \%$ da quantidade de terras aráveis (ZIBECHI, 2012). O domínio é fruto de um processo de dupla dimensão: uma dimensão estrutural, na qual o desenvolvimento do capitalismo dependente brasileiro procura as fontes de matérias-primas e energia no país, bem como consumo para suas manufaturas; e uma dimensão conjuntural, na qual a ditadura militar no país vizinho recorreu à outorga de terras e fontes energéticas a empresas brasileiras como forma de 
integração na contraofensiva regional aos movimentos de luta por terra e mesmo como um elemento da dependência mútua das ditaduras nacionais:

A ditadura fez a sua parte adjudicando de forma irregular 12.000.000 de hectares, a metade da terra arável do país que muitas vezes terminou em mãos estrangeiras (...). Mas este processo continuou em democracia, dado que entre 1989 e 2003 se adjudicaram de modo irregular quase 1.000.000 de hectares (...). Mas o fato de que se tenham instalado em zona limítrofe tem grandes repercussões sociais e econômicas. Em alguns distritos fronteiriços, como Nueva Esperanza e Katueté em Canindeyú, $58 \%$ e $83 \%$ dos proprietários são brasileiros respectivamente. Isto facilita o contrabando e o controle da seguridade fronteiriça que é estratégica para a soberania de um país. Este processo de ocupação territorial dilui as fronteiras a favor do país e o Estado mais poderoso e fragiliza ainda mais o país mais débil que terá cada vez menos instrumentos e capacidades para defender-se e controlar suas riquezas (ZIBECHI, 2012, p. 286-288).

Esta presença condiciona também fluxos migratórios muito específicos ao Brasil, atraídos pela imagem de um país em expansão econômica. Cada vez mais e mais paraguaios passam a migrar ao Brasil com esta esperança. Encontram, todavia, uma estrutura social e trabalhista de hierarquização e subalternização étnica e de classe que Ihes destina empregos e relações de produção assentadas na super exploração da força de trabalho. Reproduz-se, com isto, o capitalismo dependente. No caso específico do Haiti, o que ocorre não difere muito: a presença militar e econômica no país condiciona a formação de fluxos emigratórios ao Brasil de contingentes populacionais sem qualquer possibilidade de reprodução de sua existência no país de origem. Se suas condições econômicas, políticas e sociais já estavam historicamente deterioradas, predominando formas criminais de sobrevivência, existência de grupos armados e terrorismo de Estado (CASTOR, 2008), após o terremoto de janeiro de 2010, estas condições se agravaram, com a morte de mais de 200 mil pessoas.

O Brasil, então, desponta como um destino emigratório importante, em especial com a crise capitalista nos países de centro (como Estados Unidos e França). Os passos e percalços desta trajetória migratória serão objeto das próximas seções deste artigo. 


\section{O Haiti é aqui: imigrantes haitianos em Balneário Camboriú}

As informações que se seguem são referentes à pesquisa de campo realizada em Balneário Camboriú, cidade litorânea do estado de Santa Catarina, localizada a $81 \mathrm{~km}$ da capital estadual (Florianópolis). A pesquisa foi realizada com a aplicação de questionários semi estruturados, aplicados inicialmente no ambiente de trabalho, com anuência dos gerentes e permissão de registro de imagem do entrevistado. Com o desenvolvimento da pesquisa de campo, os questionários passaram a ser aplicados na sede da Associação dos Haitianos de Balneário Camboriú (ASHABC), situada em um bairro de periferia da cidade. As entrevistas foram realizadas entre os dias 11 de fevereiro e 15 de março de 2014. Ao todo, foram entrevistados 18 haitianos, todos eles trabalhadores do setor de supermercados e construção civil, exceto Jennie ${ }^{3}$, a única mulher entrevistada, que trabalha como diarista ${ }^{4}$. Algumas reveladoras entrevistas foram feitas com gerentes de supermercados e empregadores. Abordaremos a seguir, com a mediação de estudos anteriores (PATARRA, 2012), os principais elementos encontrados nas respostas aos questionários.

A maioria dos haitianos (15 em um total de 18, ou seja, 83,33\%) deixou o país através de um voo entre a capital de seu país, Porto Príncipe, e a cidade de Quito, no Equador. Neste sentido, o fluxo específico de haitianos em Balneário Camboriú se assemelha ao fluxo geral de haitianos no Brasil. Como observa Patarra (2012) para o caso

\footnotetext{
3 Nome fictício. Todas as identidades dos haitianos entrevistados serão preservadas utilizando nomes fictícios. Todas as demais informações são fidedignas. Ademais, o reduzido volume de nossa amostra (18 imigrantes entrevistados) inviabiliza qualquer generalização das conclusões tiradas neste artigo. Não nos parece lícito tecer conclusões sobre o universo dos imigrantes haitianos residentes em Balneário Camboriú a partir desta amostra entrevistada. Todavia, para efeitos de exposição e entendimento, utilizaremos cálculos de porcentagem para categorizar as respostas aos questionários aplicados a esta amostra. Reforça-se, contudo, que estas porcentagens fazem sempre menção exclusivamente à amostra de 18 entrevistados, e não ao universo dos imigrantes haitianos na cidade.

4 Como dito,este artigo objetiva uma primeira aproximação à presença haitiana em Balneário Camboriú. $\mathrm{A}$ metodologia da aplicação do questionário e das entrevistas, que começaram no ambiente de trabalho e daí seguiram à associação dos haitianos, acabou por nos apresentar principalmente aqueles haitianos que estavam empregados naquele setor (supermercado e construção civil) e presentes, em determinados dias, na associação. Isto excluiu um cenário importante e muito rico de especificidades que é a mulher imigrante haitiana. É neste sentido que a pesquisa avançará no curto prazo: a análise específica da migração feminina e a elaboração, assim, de um estudo mais completo sobre o fluxo.
} 
geral brasileiro:

o processo de entrada desses imigrantes em território brasileiro é semelhante na quase totalidade dos casos. A viagem começa em Porto Príncipe ou na República Dominicana, e por via aérea chegam a Lima, Peru, ou em Quito, no Equador, países que não exigiam visto de entrada para os haitianos. Destas duas cidades partem por via terrestre em uma viagem que pode se estender por mais de um mês, ao longo do percurso eles vão alternando trechos percorridos em ônibus e barcos" (PATARRA, 2012, p. 13-14).

A viagem longa a que se refere Patarra é até a fronteira do Brasil com o Peru, nos estados do Acre e do Amazonas. Estes imigrantes que chegaram à América do Sul desembarcando em Quito, chegaram ao Brasil deslocando-se de ônibus de Quito ao estado do Acre. Apenas dois imigrantes dos 18 (11,11\%) entraram via o estado de Amazonas e três imigrantes (16,67\% do total) chegaram diretamente de avião à cidade de São Paulo. Mais uma vez, este movimento particular confirma a regra geral dos haitianos no Brasil.

\begin{abstract}
Os principais pontos de entrada no Brasil são as fronteiras do Peru com os Estados do Acre e Amazonas. Ao chegarem à fronteira, estes imigrantes apresentam uma solicitação de refúgio, alegando as péssimas condições de vida no Haiti e a impossibilidade de se continuar vivendo naquele país após o terremoto. Sendo o Brasil signatário das convenções sobre $o$ acolhimento de refugiados, as autoridades na fronteira registram estas solicitações e as encaminha ao órgão competente: o Comitê Nacional para Refugiados - CONARE, do Ministério da Justiça, para análise. Enquanto aguardam a tramitação do pedido de refúgio, os imigrantes recebem uma documentação provisória (Cadastro de Pessoa Física - CPF e Carteira de Trabalho) que lhes permite circular pelo país na busca por trabalho" (PATARRA, 2012, p. 14).
\end{abstract}

Os haitianos residentes em Balneário Camboriú não escapam a esta lógica: a maioria deles chegou ao Brasil clandestinos, sem os documentos necessários à fixação de um estrangeiro no país. A tabela 1 apresenta as informações sobre sua condição de chegada, se documentada ou indocumentada: 
Tabela 1 - Condição de chegada dos imigrantes haitianos entrevistados.

\begin{tabular}{|l|r|r|}
\hline Condição de chegada & Porcentagem & Total \\
\hline Documentada & 16,67 & 3 \\
\hline Indocumentada & 83,33 & 15 \\
\hline Total & $\mathbf{1 0 0}$ & $\mathbf{1 8}$ \\
\hline
\end{tabular}

Fonte: Entrevistas realizadas pelo autor.

Os três haitianos que chegaram ao Brasil documentados (Albert, Clarkson e Pierre) tiveram como ponto de chegada não as cidades fronteiriças do Acre, mas São Paulo. Clarkson, de 33 anos de idade, chegou ao Brasil em 12 de novembro de 2012, com visto de permanência por cinco anos, obtido na embaixada brasileira em Santo Domingo. Como dito, a posse do visto o livrou de se submeter à longa viagem entre Equador ou Lima e o estado do Acre. Pelo contrário, viajou diretamente de Santo Domingo a Navegantes, com escalas na Cidade do Panamá e em São Paulo. De Navegantes, foi imediatamente a Balneário Camboriú, onde sua mulher, Ayllen, que viera antes à cidade, o esperava. Um dia após chegar a Balneário Camboriú, Clarkson foi a Itajaí, onde há um escritório da Polícia Federal. Lá obteve a sua cédula de identidade estrangeira, com validade até 2017.

Jeremie, de 32 anos de idade, é um exemplo dos outros 15 imigrantes que chegaram clandestinos ao País. Sua viagem foi, por consequência, mais longa e perigosa. Do Haiti, viajou de ônibus à República Dominicana, país vizinho na ilha caribenha, de onde viajou de avião até a Cidade do Panamá. Do Panamá, embarcou de avião até Quito, onde iniciou uma viagem de seis dias de ônibus até o Acre, passando por Lima. Ficou dois meses em péssimas condições naquele estado. Quando regularizou sua situação, obtendo um CPF e uma Cédula de Identidade de Estrangeiro, viajou a Balneário Camboriú, recrutado pela empresa Imbrasul Construtora e Incorporadora. No dia 17 de novembro de 2011 chegava à cidade. Dois anos e dez dias depois, vieram sua esposa e seu filho. Jeremie recordou na entrevista que trabalhou intensamente em dois empregos para juntar, depois destes dois anos, $\mathrm{R} \$ 5.470$ para a compra das passagens da esposa e do filho.

A trajetória de Jeremie e de cada um dos imigrantes haitianos que chega indocumentado ao Brasil e hoje vive e trabalha em cidades do sul do País suscita uma 
importante questão: uma vez situados no Acre ou no Amazonas, que fatores atraíram estes haitianos ao pequeno município de Balneário Camboriú, de apenas 108.089 habitantes, segundo o último Censo Demográfico brasileiro, e distante dos grandes centros industriais, como São Paulo, Rio de Janeiro, Porto Alegre e Belo Horizonte? A resposta a esta questão, importante para situarmos a trajetória migratória no espaço e investigarmos se Balneário Camboriú é mais um destino final ou uma etapa migratória, tem respostas diferentes segundo o momento do fluxo migratório. Atualmente, isto é, para os fluxos migratórios atuais, a resposta reside na atuação das redes sociais: os amigos e parentes que já migraram dão referências positivas do lugar àqueles que ficaram, incentivando-os a migrar e construindo uma rede de relações sociais e laborais na qual o migrante se inserirá. Previamente, já se têm garantias de emprego, hospedagem e ajuda inicial, dentro de uma rede de relações sociais centrada na conterraneidade. Todos estes elementos são facilmente observados entre os haitianos em Balneário Camboriú: a rede social, fortalecida pela criação da Associação dos Haitianos em Balneário Camboriú no dia 05 de março de 2013, é o que verdadeiramente dá sequência hoje ao fluxo, especialmente através do desejo e da iniciativa de trazer para a cidade os parentes que ficaram no Haiti. Todos os entrevistados declararam haver deixado a família em seu país. Isto aponta para outro elemento importante deste fluxo, e central para a economia do Haiti: as remessas de migrantes. A tabela 2 apresenta informações sobre envio de remessas aos familiares que permanecem no Haiti.

Tabela 2 - Envio de remessas aos familiares que permanecem no Haiti.

\begin{tabular}{|l|c|c|}
\hline Remessas de migrantes & Porcentagem & Total \\
\hline Envia & 72,22 & 13 \\
\hline Não envia & 11,11 & 2 \\
\hline Não respondeu & 16,67 & 3 \\
\hline Total & $\mathbf{1 0 0}$ & $\mathbf{1 8}$ \\
\hline
\end{tabular}

Fonte: Entrevistas realizadas pelo autor.

É predominante, como visto na tabela 2, a realização de remessas, mesmo sob as 
condições do mercado de trabalho em que atuam os haitianos e os elevados gastos com aluguel. O envio das remessas indica a manutenção dos laços afetivos e materiais com a família, ao passo que guarda íntimas relações com a dedicação ao trabalho, com o nível de poupança e consumo e com as estratégias econômicas familiares. Clarkson, por exemplo, envia no dia 10 de cada mês remessas no valor de $\mathrm{R} \$ 1.000,00$ a seus pais. Para tal, tem dois empregos, e sua esposa também trabalha. O compromisso das remessas se justifica pela idade avançada dos pais e pela impossibilidade de eles trabalharem no Haiti. Na mediação da saudade com a busca por uma vida melhor, Clarkson se vê entre o desejo de voltar ao Haiti em 2015 para visitar seus pais, o compromisso com o envio de remessas e a ajuda financeira para comprar passagens para que seus irmãos também possam vir morar e trabalhar em Balneário Camboriú. Sem saber, ele é um agente ativo das redes sociais dos imigrantes haitianos na cidade: veio com a ajuda da esposa que viera antes e quer tornar possível a vinda de seus irmãos.

As redes sociais, materializadas hoje no espaço de ajuda mútua, representado pela Associação dos Haitianos da cidade, são um elemento fundamental da atual conjuntura migratória internacional e de como Balneário Camboriú se insere nela. Todavia, no tempo germinal do fluxo migratório, as redes sociais são mais produto que causa destes fluxos, de modo que outro fator incidiu inicialmente na orientação da trajetória migratória dos haitianos especificamente rumo a esta cidade brasileira. As respostas aos questionários aplicados indicam haver uma forte atuação de três empresas catarinenses no recrutamento e contratação de força de trabalho, ainda no Acre. Estas empresas foram até as cidades fronteiriças daquele estado em busca da força de trabalho haitiana. Estas empresas são a Multilog, a Ambiental e a Imbrasul Construtora e Incorporadora.

A Multilog é uma empresa de logística em comércio exterior, sediada no município de Itajaí, vizinho de Balneário Camboriú. Seu principal produto é a armazenagem de bens, seu transporte para exportação, especialmente no MERCOSUL, e outros serviços conexos.

A Ambiental é uma empresa de execução de obras e de realização de serviços de limpeza urbana em nove cidades do estado de Santa Catarina: Balneário Camboriú, Camboriú, Itajaí, Itapema, Indaial, Jaraguá do Sul, Joinville, São Francisco do Sul e São 
José. Além da coleta e transporte de lixo, a Ambiental faz ainda tratamento de resíduos sólidos e operações de saneamento básico, e emprega diretamente mais de 1.800 trabalhadores.

A Imbrasul Construtora e Incorporadora é uma empresa sediada no município de Navegantes, distante $34 \mathrm{~km}$ de Balneário Camboriú. Constrói edifícios de alto padrão na região, especialmente na praia de Gravatá.

Em síntese: os primeiros haitianos em Balneário Camboriú trabalhavam como garis no município e no porto de Itajaí. Alguns haviam sido recrutados no Acre para trabalhar na construção civil em Navegantes, mas os atrativos em Balneário Camboriú (especialmente a maior oferta de emprego e acesso a serviços e a proximidade com os haitianos residentes nessa cidade) rapidamente os atraíram. Realizavam, portanto, tarefas mais intensivas no uso da força física, menos qualificadas. Foi apenas posteriormente que os trabalhadores haitianos procuraram trabalho em outros setores, principalmente o de supermercados.

A idade média dos haitianos entrevistados é de 30 anos, embora a cúspide da estrutura etária desta amostra seja o intervalo de 25 a 29 anos. O gráfico 2 permite-nos visualizar tal estrutura:

Gráfico 2 - Estrutura etária dos haitianos entrevistados.

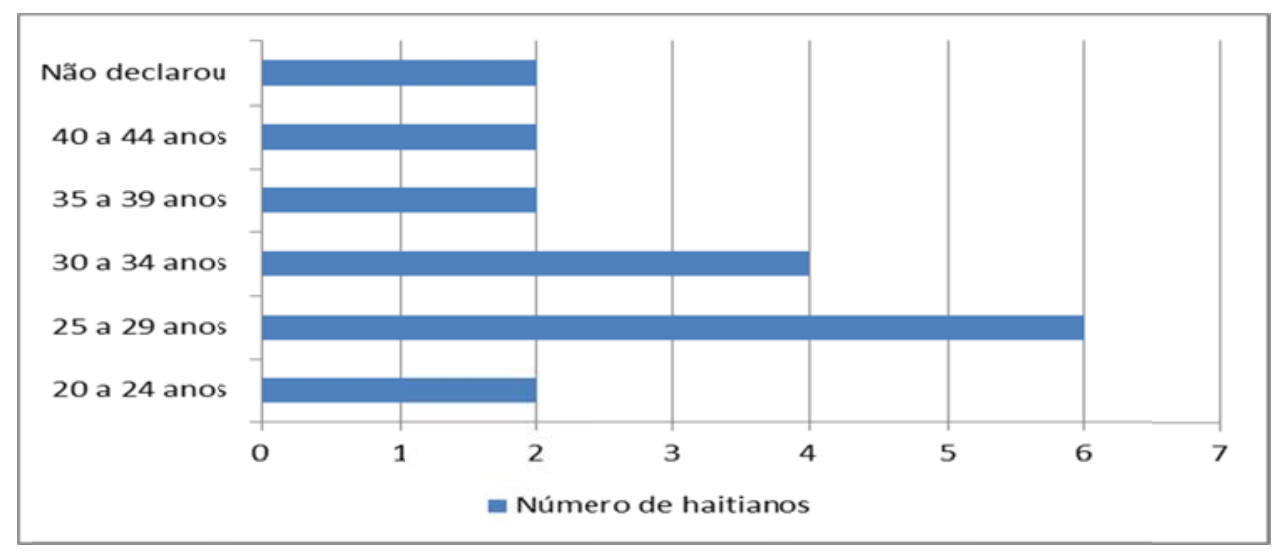

Fonte: Entrevistas realizadas pelo autor. 
O mais jovem haitiano entrevistado é Gerard, de 22 anos. O mais velho é Yves, de 44 anos. Ambos chegaram ilegais ao País. A concentração da idade dos entrevistados nos grupos etários mais produtivos revela que nossa amostra, pequena, certamente, é de pessoas que chegam a Balneário Camboriú principalmente para trabalhar.

A análise da data de sua chegada ao Brasil sugere que o fluxo ainda está em expansão. A tabela 3 apresenta informações sobre o ano de sua chegada.

Tabela 3 - Ano de chegada dos imigrantes haitianos entrevistados.

\begin{tabular}{|l|c|c|}
\hline Ano de chegada & Porcentagem & Total \\
\hline 2011 & 16,67 & 3 \\
\hline 2012 & 27,78 & 5 \\
\hline 2013 & 44,44 & 8 \\
\hline 2014 & 5,56 & 1 \\
\hline Não respondeu & 5,56 & 1 \\
\hline Total & $\mathbf{1 0 0}$ & $\mathbf{1 8}$ \\
\hline
\end{tabular}

Fonte: Entrevistas realizadas pelo autor.

A indicada expansão do volume do fluxo a cada ano apresenta não um problema, mas um desafio aos responsáveis pela política migratória nacional, os prefeitos e gestores das cidades com presença imigrante e toda a sociedade do local de destino: dar-lhes acolhida, criar as condições sociais, econômicas e laborais para que não haja discriminação, e estender a eles os serviços e direitos consagrados pela Constituição Federal brasileira.

Quando perguntados sobre o desejo de voltar ao Haiti, os entrevistados tiveram de fazer um balanço principalmente entre a saudade dos familiares que ficaram, as condições de vida e de trabalho em Balneário Camboriú, além de suas perspectivas, e as duras condições de vida reinantes no Haiti. O resultado desta mediação não foi uniforme, conforme se pode observar na tabela 4. 
Tabela 4 - Desejo de retorno ao Haiti.

\begin{tabular}{|l|c|c|}
\hline Retorno ao Haiti & Porcentagem & Total \\
\hline Deseja voltar & 55,56 & 10 \\
\hline Não deseja voltar & 27,78 & 5 \\
\hline Deseja apenas para visiť & 16,67 & 3 \\
\hline Total & $\mathbf{1 0 0}$ & $\mathbf{1 8}$ \\
\hline
\end{tabular}

Fonte: Entrevistas realizadas pelo autor.

Além dos 18 trabalhadores haitianos entrevistados, foram questionadas ainda duas gerentes de supermercados em Balneário Camboriú, as quais afirmaram que os haitianos "trabalham muito bem, muito contentes", destacando a felicidade com que vivem e trabalham. Em apenas um dos dois supermercados o número de trabalhadores haitianos era de 16, e havia mais uma haitiana a ser contratada. Os principais serviços dentro deste supermercado eram a cozinha, a reposição, o setor de frutas, o açougue e a padaria. Não fizeram referência, portanto, a trabalhadores haitianos no caixa e no empacotamento das compras - e na própria gerência do supermercado. As gerentes afirmaram ser prática dos supermercados contratar apenas aqueles que possuem o Registro Nacional de Estrangeiro (RNE). Destacaram que os haitianos recebem a mesma remuneração dos trabalhadores brasileiros. Esta informação foi confirmada por cinco haitianos entrevistados ( $27,78 \%$ do total) e negada por três (16,67\% do total). Outros dez $(55,56 \%)$ preferiram não responder a esta questão. As gerentes lembraram ainda de uma exigência particular da Agência Nacional de Vigilância Sanitária (ANVISA): exames admissionais específicos, mais completos e complexos que aqueles feitos com os trabalhadores brasileiros. Outro fator destacado pelas gerentes foi a diferença de postura dos haitianos que chegam recentemente em relação aos primeiros que migraram a Balneário Camboriú: afirmaram que a indisciplina, o uso de drogas e o alcoolismo está mais presente atualmente, nos fluxos mais recentes. Há uma espécie de referência saudosa aos primeiros imigrantes, tidos geralmente como "muito bons". 
Se a visão dos moradores locais sobre os haitianos suscita temas, objetivos e subjetivos, importantes para a análise de sua integração social, a visão específica dos empregadores e gerentes é ainda mais interessante. Neste sentido, a referência constante à limpeza pessoal que apresentam chama imediatamente atenção, não passando despercebida certa dose de surpresa em relação a esta característica - e por que não poderiam ser limpos? A "aparência impecável” e a "limpeza pessoal” são, inclusive, fatores que incidem na própria contratação do trabalhador, especialmente naqueles serviços de supermercado que atendem mais ao público. Esta e muitas outras questões específicas do povo haitiano fazem perceber a importância de se conhecer a sua história, de se respeitar sua cultura, para o entendimento de sua condição humana particular. Um povo que conheceu cedo o valor da liberdade, e que hoje descobre em Balneário Camboriú o valor de sua mobilidade.

\section{Conclusões}

Embora recente, o fluxo migratório de haitianos em Balneário Camboriú estabelece conexões e vínculos históricos com fenômenos centrais do capitalismo contemporâneo, como a formação das desigualdades nacionais, o desenvolvimento do capitalismo dependente tanto na origem como no destino do fluxo, e a atuação do subimperialismo brasileiro. Portanto, entendemos como válido e necessário um estudo ulterior destes temas, de modo a situar materialmente no tempo e no espaço a especificidade deste fluxo.

A categoria do subimperialismo revelou grande capacidade explicativa a questionamentos a respeito do fluxo de haitianos no Brasil. Perguntas como "por que o Brasil?", “por que só agora?" e "por que neste volume?", se não completamente respondidas, foram ao menos esclarecidas com o recurso à categoria do subimperialismo, e a análise acurada da presença brasileira no Haiti como promovedora da presença de habitantes daquele país no Brasil. Não são, logicamente, fenômenos que se relacionam 
como causa e efeito, de forma mecânica, mas sim fenômenos que, no âmbito das migrações internacionais, não podem ser dissociados, e devem ser vistos como produto e produtores do desenvolvimento desigual no espaço e da mobilidade neste próprio espaço como estratégia de sobrevivência - de forma dialética, portanto.

Embora este artigo se refira a um fluxo migratório que possui origem (Haiti) e destino (Balneário Camboriú) bem definidos, é inegável que estamos diante de um fenômeno latino-americano. Seja como etapa migratória ou apenas como ponto de conexão, pelos menos outros três países do continente (República Dominicana, Equador e Peru) e outros três estados brasileiros (Acre, Amazonas e São Paulo), estão presentes, em maior ou menor medida, nesta dinâmica. Como fenômeno latino-americano que é, este fluxo carrega em si a síntese de um continente marcado pela migração como estratégia material de sobrevivência, e pela apropriação desta migração pelo capital (as empresas que submetem os migrantes a taxas adicionais de exploração) como estratégia de acumulação.

A presença haitiana no estado impõe, ademais, um desafio ao registro teórico das migrações em Santa Catarina: romper com a tradição de construção de narrativas epopeicas, de supervalorização da saga imigrante italiana e alemã, de um lado, e, de outro,de romper o silêncio sobre a presença negra, indígena e mesmo árabe em nosso estado. Este desafio está posto neste momento e o presente artigo se coloca ao lado do povo haitiano na valorização de sua história, motivo do resgate do passado desse país.

Por fim, os haitianos trazem consigo uma contradição pulsante na América Latina: o subimperialismo brasileiro, que atua em seu país militar, econômica e politicamente, que colabora na repressão aos movimentos sociais, que aprofunda a própria condição de dependência - inclusive a sua - deve ser superado pela integração latino-americana, a construção de uma alternativa comum aos países do continente, a valorização de nossa identidade histórica, cindida por séculos de colonialismo e imperialismo. O convívio pacato e afetuoso entre os Clarkson, Jeremie, Gerard, Jennie e Alberts do Haiti com os José, Maria, Pedro, Henrique e Luanas do Brasil deve servir de pista à resolução da contradição atualmente existente em nosso continente: subimperialismo ou integração. 


\section{Referências}

BAGÚ, Sérgio. Economía de la sociedad colonial. Madrid: Akal, 1977.

BINFORD, Leigh. Remesas y Subdesarrollo en México. Revista Relaciones. Benemérita Universidad Autónoma de Puebla, n. 90, v. XXIII, Pg. 116 - 158, Primavera 2002.

BRITO, Fausto. Os povos em movimento: as migrações internacionais no desenvolvimento do capitalismo. In: PATARRA, Neide Lopes (Org.). Emigração e imigração internacionais no Brasil contemporâneo.v. 1. Campinas: Programa Interinstitucional de Avaliação e Acompanhamento das Migrações Internacionais no Brasil, 1995. p. 53-66.

CASTOR, Suzy. A Transição haitiana: entre os perigos e a esperança. Cadernos de Pensamento Crítico Latino-Americano, n. 2, p. 11-24.

COVARRUBIAS, Humberto Márquez. Desarrollo y migración: una lectura desde la economia política.Revista Migración y Desarrollo, n. 14, p.59-87, primeiro semestre de 2010.

CUEVA, Agustín, El desarrollo del capitalismo en América Latina: ensayo de interpretación histórica. México, D.F: Siglo XXI Editores, 1990. 275p.

DURAND, Jorge. Racismo y migración. La Jornada: opinión. Disponível em: <http://www.jornada.unam.mx/2013/10/06/opinion/020a1pol>. Acesso em: mar. de 2014.

FRANK, André Gunder. América Latina: subdesarrollo o revolución. México, D.F: Ediciones Era, $1973.358 \mathrm{p}$.

GAUDEMAR, Jean-Paul. Mobilidade do trabalho e acumulação de capital. Lisboa: Editorial Estampa, 1977. 408 p.

GROSFOGUEL, Ramón. Migrantes Coloniales Caribeños em los Centros Metropolitanos del Sistema-Mundo. Los casos de Estados Unidos, Francia, los Países Bajos y el Reino Unido. Documentos CIDOB, v. 13 - série migraciones, p. 01-51, Junho de 2007.

Instituto Brasileiro de Geografia e Estatísticas (IBGE). Banco de Dados Países. Disponível em: <http://www.ibge.gov.br/paisesat/>. Acesso em: abr. 2014.

JAMES, Ceryl L. R. Os Jacobinos Negros. São Paulo: Boitempo Editorial, 2010. 400 p.

LUCE, Mathias S. A teoria do subimperialismo em Ruy Mauro Marini: contradições do capitalismo dependente e a questão do padrão de reprodução do capital. A história de 
uma categoria. Tese (Doutorado em História.). Universidade Federal do Rio Grande do Sul. 2011. 00 f. Porto Alegre, 2011.

MARINI, Ruy Mauro. Dialética da dependência. Petrópolis: Vozes, 2000. 295 p.

MARINI, Ruy Mauro. Subdesenvolvimento e revolução. $2^{\mathrm{a}}$ ed. Florianópolis: Insular, 2012. $272 \mathrm{p}$.

MARTES, Ana Cristina Braga. Brasileiros nos Estados Unidos: um estudo sobre imigrantes em Massachusetts. São Paulo: Paz e Terra, 2000. 208 p.

MARX, Karl; ENGELS, Friedrich. Manifesto do Partido Comunista. Porto Alegre: L\&PM Pocket, 1848/2009. 144 p.

PATARRA, Neide Lopes. O Brasil: país de imigração? Revista E-Metropolis, n. 09, ano 3, p. 01-18, junho de 2012.

SALES, Teresa. Migrações de fronteira entre o Brasil e os países do MERCOSUL. Revista Brasileira de Estudos Populacionais (REBEP), Campinas, v. 13, n. 1, p. 87-98, 1996.

SASSEN, Saskia. The mobility of labor and capital: A study in international investiment and labor flow. Cambridge: Cambridge University Press, 1988.

SCHUMPETER, Joseph A. História da análise econômica. São Paulo: Fundo de Cultura, 1964.

SINGER, Paul. Economia política da urbanização. 15ª ed. São Paulo: Brasiliense, 1995. 154 p.

WILLIAMS, Eric. Capitalismo e escravidão. Rio de Janeiro: Americana, 1975.

WORLD BANK. The Factbook of migration and remittances. Disponível em:

<http://www.worldbank.org/>. Acesso em: jan. de 2014.

ZIBECHI, Raúl. Brasil potencia: entre la integración regional y un nuevo imperialismo.

Santiago de Chile: Editorial Quimantú, 2012.392 p. 
O Haiti é aqui: primeiros apontamentos sobre imigrantes haitianos em Balneário Camboriú - Santa

Catarina - Brasil

Luís Felipe Aires Magalhães

\section{Anexos}

Imagem 1 - Trabalhador haitiano no setor de frutas e verduras de um Supermercado em Balneário Camboriú - SC.

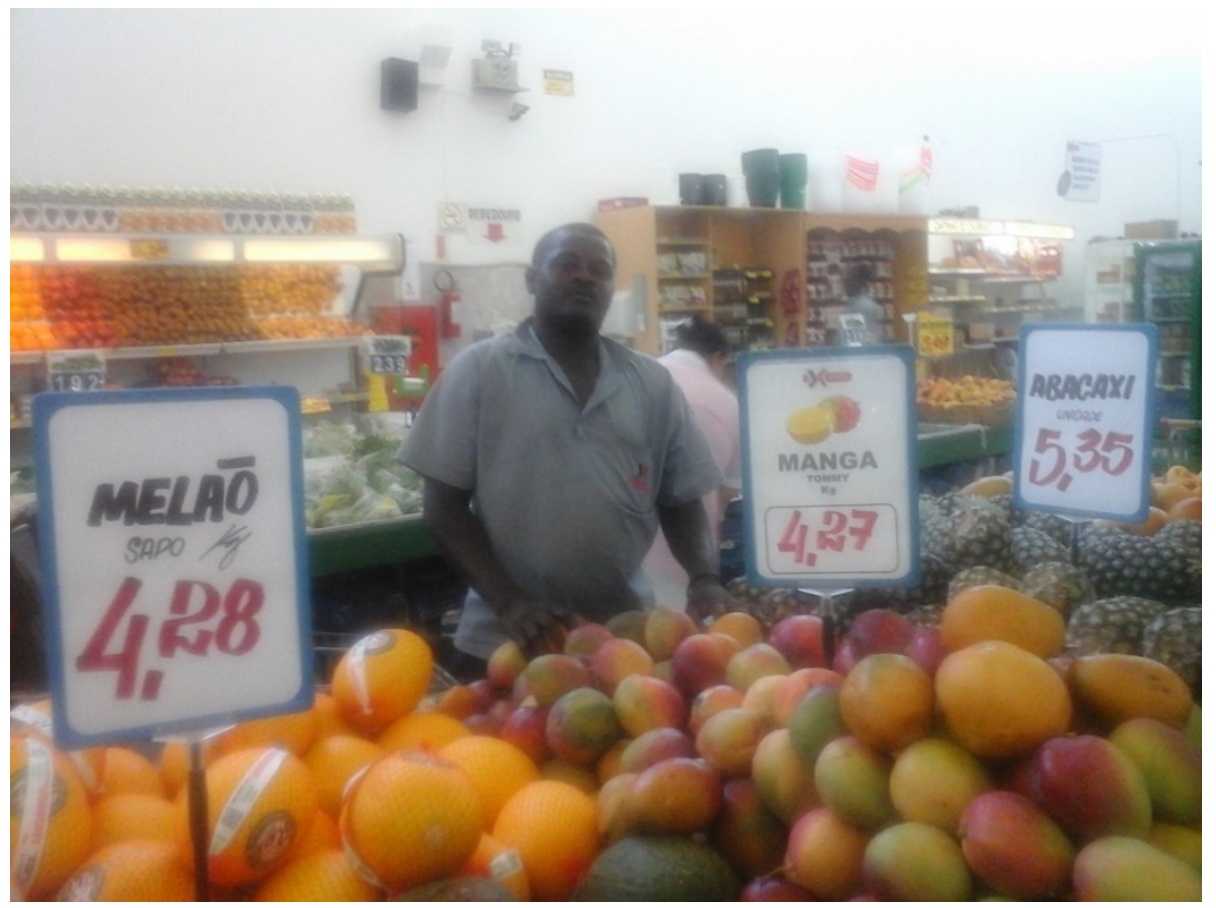

Imagem 2 - Trabalhador haitiano no setor de frutas e verduras de um Supermercado em Balneário Camboriú - SC.

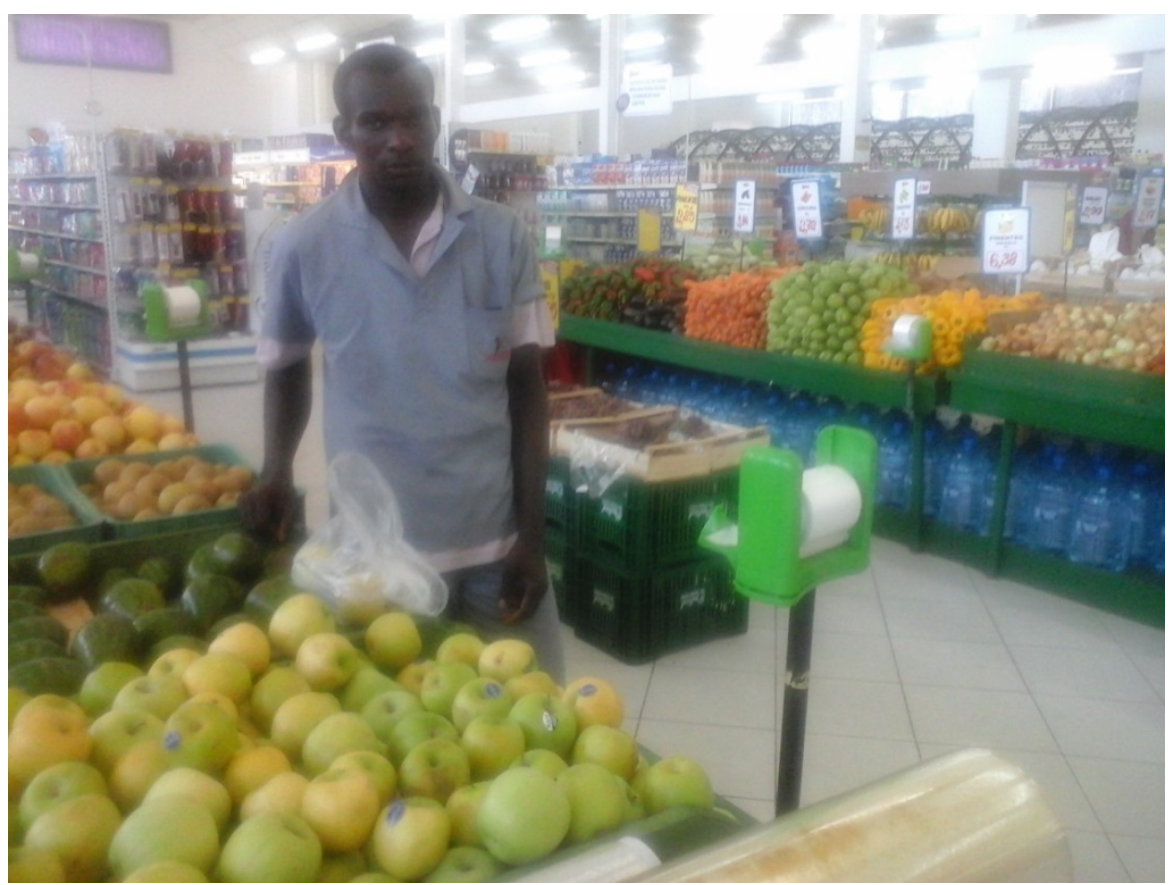


O Haiti é aqui: primeiros apontamentos sobre imigrantes haitianos em Balneário Camboriú - Santa

Catarina - Brasil

Luís Felipe Aires Magalhães

Imagem 3 - Os haitianos hoje são uma presença constante em serviços de supermercado, construção civil e limpeza urbana na cidade.

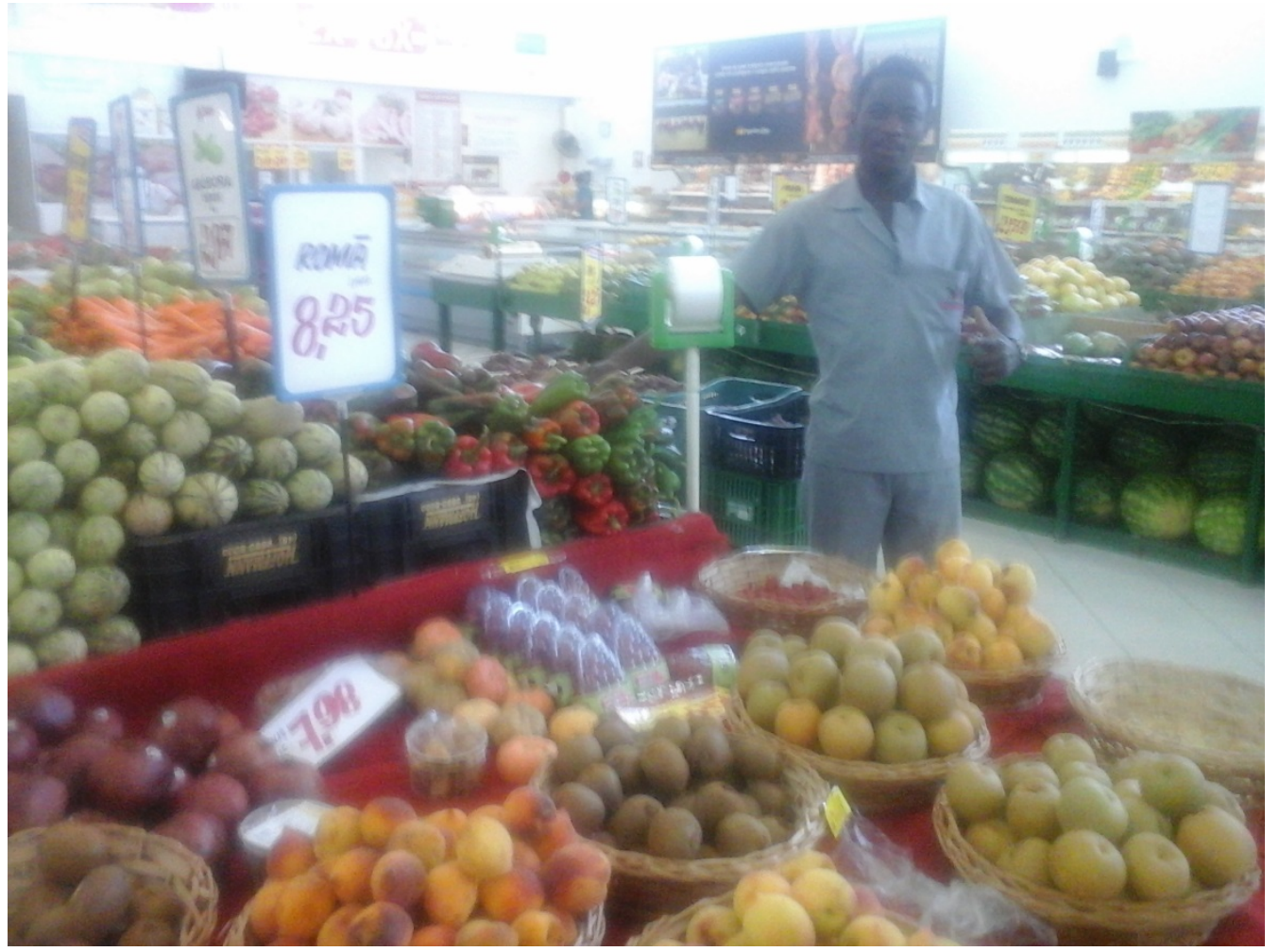

Imagem 4 - Na Associação dos Haitianos de Balneário Camboriú (ASHABC), os computadores são utilizados como forma de comunicação com os familiares que permanecem no Haiti.

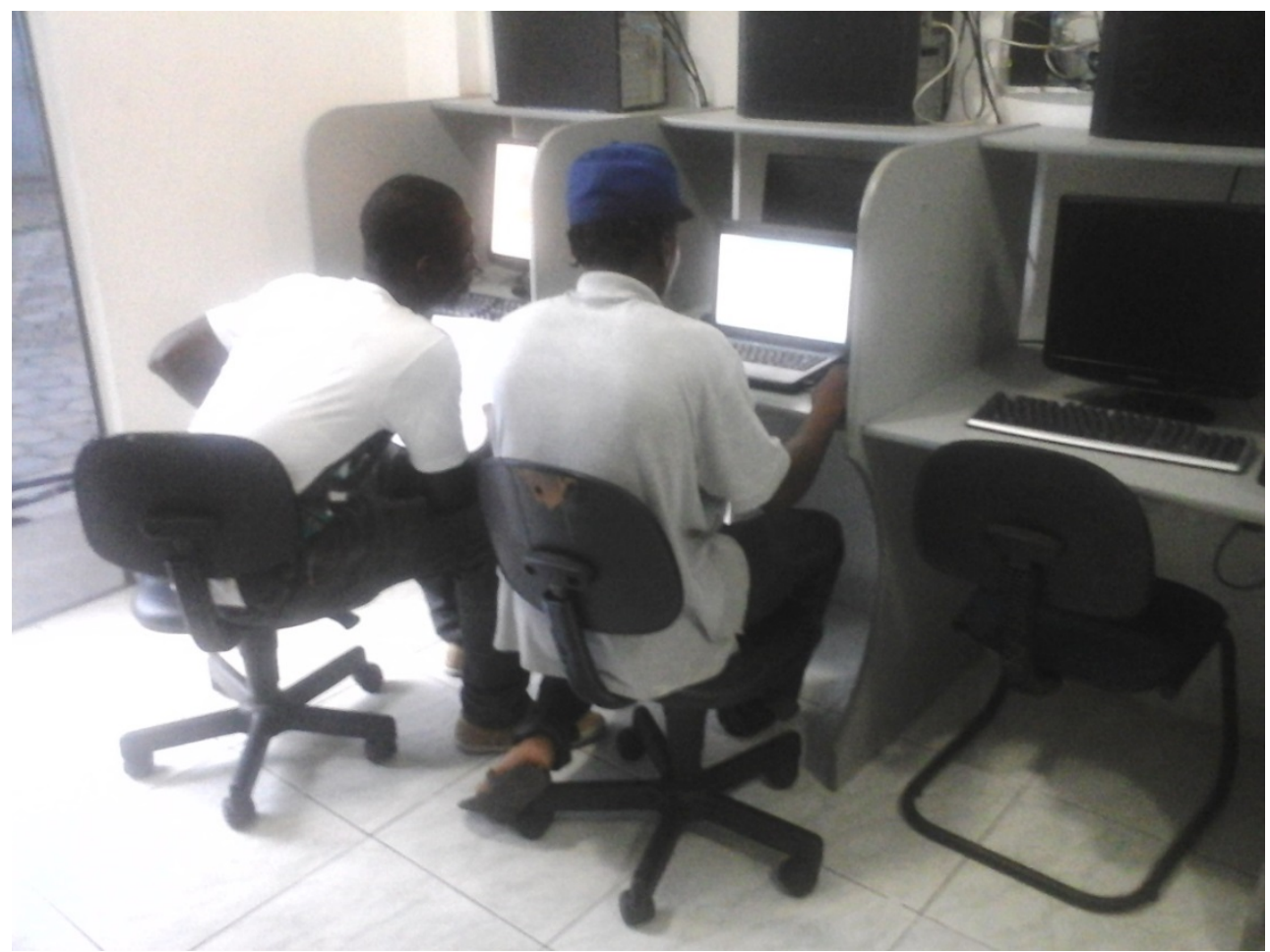


O Haiti é aqui: primeiros apontamentos sobre imigrantes haitianos em Balneário Camboriú - Santa

Recebido em: 19/03/2014 Aprovado em: 14/04/2014

Universidade do Estado de Santa Catarina - UDESC 